Article

\title{
Equilibrium and Kinetic Studies of Biosorptive Removal of 2,4,6-Trichlorophenol from Aqueous Solutions Using Untreated Agro-Waste Pine Cone Biomass
}

\author{
Nadavala Siva Kumar ${ }^{1, * \mathbb{D}}$, Mohammad Asif ${ }^{1}{ }^{\mathbb{D}}$, Anesh Manjaly Poulose ${ }^{1}$, Madala Suguna ${ }^{2}$ and \\ Mansour I. Al-Hazza ${ }^{1}$ \\ 1 Department of Chemical Engineering, King Saud University, P.O. Box 800, Riyadh 11421, Saudi Arabia; \\ masif@ksu.edu.sa (M.A.); apoulose@ksu.edu.sa (A.M.P.); masai@ksu.edu.sa (M.I.A.-H.) \\ 2 Vemu Institute of Technology, P. Kothakota, Chitoor, Andhra Pradesh 517112, India; \\ madala.suguna@gmail.com \\ * Correspondence: shivanadavala@gmail.com or snadavala@ksu.edu.sa; Tel.: +966-537-228-108
}

Received: 25 September 2019; Accepted: 12 October 2019; Published: 16 October 2019

\begin{abstract}
The present work discusses the adsorptive removal of a phenolic pollutant, i.e., 2,4,6-trichlorophenol (TCP), using low cost untreated agricultural waste pine cone powder (PCP). The present biosorbent was thoroughly characterized with the help of FTIR, SEM, XRD, and CHN analysis. The presence of amine $\left(-\mathrm{NH}_{2}\right)$, hydroxyl $(-\mathrm{OH})$ and carbonyl $(\mathrm{C}=\mathrm{O})$ functional groups was detected by the FTIR analysis. The important biosorption factors like agitation time, biomass dosage, initial adsorbate concentration, and the initial $\mathrm{pH}$ were examined by batch studies. The biosorption kinetic process was fast, reaching equilibrium in $75 \mathrm{~min}$. The experimental kinetic data revealed an excellent agreement with the pseudo second order (PSO) model. On the other hand, the Langmuir isotherm model best described the equilibrium data with the maximum biosorption capacity $\left(q_{\max }\right)$ of $243.90 \mathrm{mg} / \mathrm{g}$. These values are better than the adsorption capacities of most agro-based untreated adsorbents previously reported in the literature. Owing to fast removal rates and high biosorption capacity, PCP can be used for cost-effective treatment of TCP from aqueous streams.
\end{abstract}

Keywords: biosorption; pine cone powder; 2,4,6-trichlorophenol; kinetics and isotherm models

\section{Introduction}

The phenolic derivatives are widely used as herbicides, pharmaceuticals, dyes, fungicides, algicides, insecticides, ovicides, preservatives, and numerous intermediate compounds [1]. The removal of chlorophenols such as 2,4,6-Trichlorophenol (TCP) from contaminated wastewater is essential because of their high toxicity, carcinogenicity, teratogenicity, mutageneticity, persistency, and low biodegradability. Its accumulation can cause serious environmental damage and harm the human health through direct exposure [2,3]. Effluents released from agricultural irrigation, petroleum refineries, pharmaceutical drugs, pulp and paper industries, synthetic resins, pesticides and industrial waste-water from paints are often heavily contaminated with chlorophenolic compounds [4,5]. Even at trace levels, these compounds can affect aquatic-life and lead to an accumulation in the food chain. Chlorinated phenols are highly toxic to both human and aquatic lives [6,7]. Moreover, chlorinated phenols are carcinogenic for animals, and are reported to cause leukemia, liver cancer, and lymphomas via oral exposure. In fact, 2,4,6-trichlorophenol has been classified as a probable human carcinogen (Group B2) by EPA (ATSDR, U.S. Public Health Service, Atlanta, GA. 1990) [8]. Therefore, it is essential 
to develop cost-effective treatment strategy for the contaminated waste-water prior to release into the environment.

The elimination of organic contaminants from the waste-water effluents using various methods like physical (membrane filtration, adsorption, biosorption and solvent extraction), chemical-biological oxidation, electrochemical oxidation, photocatalytic degradation, microbial degradation, ion exchange resins, catalytic oxidation, advanced oxidation processes have been proposed in the recent literature [9-12]. Among these techniques, the biosorption using various agricultural wastes has been thoroughly investigated for the elimination of organic contaminants and heavy metals from the standpoint of cost-effectiveness and eco-friendly considerations [13-17]. Several studies proved biosorption is a simple yet effective method for the elimination of pollutants, in which the significant factor is the utilization of agricultural wastes. Many authors highlighted the fact that the biosorption of phenol and phenolic derivatives using lignocellulosic residues and agricultural by-products do not require recycling and regeneration studies due to their low-cost and abundant availability in nature [2,18-21].

Pine trees annually produce large amounts of pine cones as an agricultural waste. Each cone consists of an axis, which is composed of several woody scales arranged in a spiral fashion. These scales comprise of epidermal and a sclerenchyma cell, which is mainly composed of lignin, tannins, and rosin etc. besides cellulose and hemicelluloses in their cell wall structures [22]. Pine cone biomass have newly used for removing heavy metals, dyes, and phenols from aqueous media [23-28]. However, its use for removing chlorophenols from contaminated wastewater has not yet been reported in the literature.

Despite being a common pollutant found in the environment, the biosorptive removal of TCP using pinecone biomass, to our knowledge, has not yet been discussed in the literature. Therefore, the present study examines the biosorption efficacy of the untreated PCP to remove TCP from contaminated waste-water. The biosorbent characterization was carried out with the help of FTIR, BET, SEM, XRD and $\mathrm{CHN}$ analysis. Several key factors influence the sorption of TCP, such as the solution $\mathrm{pH}$, agitation time, biosorbent dosage, and the initial concentration of TCP were studied for greater understanding and subsequent optimization of the biosorption process.

\section{Materials and Methods}

\subsection{Materials}

2,4,6-Trichlorophenol $\left(\mathrm{C}_{6} \mathrm{H}_{3} \mathrm{Cl}_{3} \mathrm{O}\right)$ has a molecular weight of $197.46 \mathrm{~g} / \mathrm{mol}$. We first prepared $1000 \mathrm{mg} / \mathrm{L}$ stock solution of analytical grade TCP (Aldrich, St. Louis, MO, USA). The experimental solutions of concentration varying from 100 to $400 \mathrm{mg} / \mathrm{L}$ were prepared by diluting the original stock solution in required proportions. The $\mathrm{pH}$ of the solution was adjusted in the range of $2.0-10$ by adding $0.1 \mathrm{M}$ acid $(\mathrm{HCl})$ or base $(\mathrm{NaOH})$ solutions.

\subsection{Preparation of Pine Cone Biosorbent}

Pine trees produce large amounts of pine cone as agricultural waste. The first step was to wash with distilled water for removing impurities, e.g., leaves and sand. Pine cones were then dried in an oven maintained at $80^{\circ} \mathrm{C}$ for $48 \mathrm{~h}$. The next step involved removal of the scales from cones and blending the sample with the help of a food processing blender. We then ground the blended sample to get a fine powder of wide size distribution. The pine cone powder was finally obtained by using Mesh 200 and Mesh 270 sieves, which yielded biosorbent particles in the size range of 53-74 $\mu \mathrm{m}$. This final product was named ' $\mathrm{PCP}$ ' (Pine cone powder) and used without any further treatment for chlorophenol biosorption studies.

\subsection{Batch Biosorption Studies}

The biosorption equilibrium was investigated by carrying out batch experiments using amber glass reagent bottle ( $125 \mathrm{~mL}$ capacity) containing $0.1 \mathrm{~g}$ PCP in $100 \mathrm{~mL}$ solution containing TCP with a $100-400 \mathrm{mg} / \mathrm{L}$ concentration. We stirred the samples using a shaking water bath at $220 \mathrm{rpm}$ with 
controlled temperature $\left(30 \pm 1{ }^{\circ} \mathrm{C}\right)$ till steadiness was attained. The solution $\mathrm{pH}$ was varied in the range of 2-10. For filtration, a paper filter with $2.7 \mu \mathrm{m}$ size particle retention was used to get the supernatant solution. TCP concentration was measured using UV-Vis spectrophotometer (Model: Shimadzu UV-1601, Tokyo, Japan) at a wavelength of $296 \mathrm{~nm}$.

In order to determine the biosorption uptake capacity $\left(q_{e}, \mathrm{mg} / \mathrm{g}\right)$ and the removal efficiency, following equations were utilized,

$$
\begin{gathered}
q_{e}=\frac{\left(C_{0}-C_{e}\right) V}{W} . \\
\text { Removal }(\%)=\frac{\left(C_{0}-C_{e}\right) \times 100}{C_{0}}
\end{gathered}
$$

where, $q_{e}=$ equilibrium biosorption capacity, $C_{0}=\mathrm{TCP}$ concentration $(\mathrm{mg} / \mathrm{L})$ at time $=0, C_{e}=\mathrm{TCP}$ concentration $(\mathrm{mg} / \mathrm{L})$ at equilibrium, $V=$ volume $(\mathrm{L})$ of the solution, $W=\mathrm{PCP}$ biosorbent mass $(\mathrm{g})$.

During batch kinetics studies, the TCP uptake, $q_{t}(\mathrm{mg} / \mathrm{g})$, at time $t$ was calculated using,

$$
q_{t}=\frac{V\left(C_{0}-C_{t}\right)}{W}
$$

where, $C_{t}$ is the concentration of solute $(\mathrm{mg} / \mathrm{L})$ at time, $t(\mathrm{~min})$.

\subsection{Normalized Standard Deviation}

The validity of the kinetic and equilibrium isotherm models was evaluated using the normalized standard deviation. Mathematically, it can be represented [29] as follows:

$$
\Delta q(\%)=100 \times \sqrt{\sum_{i=1}^{N} \frac{\left[\left(q_{i, \exp }-q_{i, \text { cal }}\right) / q_{i, \exp }\right]^{2}}{(N-1)}}
$$

where $q_{i, \text { exp }}$ and $q_{i, c a l}$ are time dependent investigation data and the corresponding model predictions, respectively, whereas $N$ is represent the number of data points.

\subsection{Chi-Square Test $\left(\chi^{2}\right)$}

Chi-square analysis was also carried out for comparing the agreement among the investigational data and the predictions models of kinetic and equilibrium isotherm. This is defined as [30],

$$
\chi^{2}=\sum_{i=1}^{N} \frac{\left(q_{e}-q_{e, \text { model }}\right)^{2}}{q_{e, \text { model }}}
$$

where $q_{e}$ and $q_{e, \text { model }}(\mathrm{mg} / \mathrm{g})$ are the biosorbed amount of TCP contaminant achieved experimentally and predicted by the relevant model, respectively.

\section{Results}

\subsection{Pine Cone Biomass Characterization}

Analysis of the natural PCP powder which was carried out is shown in Table 1. The ash content, $\mathrm{CHN}$, moisture content, surface properties, and bulk density. 
Table 1. Native pine cone powder (PCP) biosorbent characterization.

\begin{tabular}{cc}
\hline Property & Value \\
\hline Color & Brown \\
Carbon $(\%)$ & 76.58 \\
Hydrogen $(\%)$ & 4.84 \\
Nitrogen $(\%)$ & 6.52 \\
Odor & None \\
Weight loss $(\%)$ & 48.8 \\
Apparent (bulk) density $\left(\mathrm{g} / \mathrm{cm}^{3}\right)$ & 0.42 \\
Moisture content $(\%)$ & 3.14 \\
Pore diameter $\left(\mathrm{A}^{0}\right)$ & 15.73 \\
Ash content $(\%)$ & 4.89 \\
BET surface area $\left(\mathrm{m}^{2} / \mathrm{g}\right)$ & 7.108 \\
\hline
\end{tabular}

\subsubsection{Characteristics of Native PCP and after Biosorption}

The identification of biosorbent surface functional groups in TCP biosorption was determined with the help of FTIR analyses. In Figure 1a,b shows the shift of some functional groups FTIR spectral data of the native PCP and TCP loaded PCP in the 400 to $4000 \mathrm{~cm}^{-1}$ range. The native PCP shows main broadband peaks observed at $3328 \& 2938 \mathrm{~cm}^{-1}$ are due to $\mathrm{N}-\mathrm{H}, \mathrm{O}-\mathrm{H}$ stretching vibration and aliphatic C-H stretching vibrations of $-\mathrm{CH}_{3}$ and $-\mathrm{CH}_{2}$ functional groups [20,31,32]. The peak at $1647 \mathrm{~cm}^{-1}$ show the functional group region of $\mathrm{C}=\mathrm{O}$ stretch and one more peak at $1440 \mathrm{~cm}^{-1}$ indicates the phenolic $-\mathrm{OH}$ and $-\mathrm{C}=\mathrm{O}$ is stretching of carboxylate group. While the other bands between $541,626,879,975$ and $1052 \mathrm{~cm}^{-1}$ may be attributed to the $-\mathrm{C}-\mathrm{H}$ - bending and $-\mathrm{C}-\mathrm{Cl}$ - stretching, respectively [33,34]. As shown in Figure 1b after biosorption of TCP on PCP showed small shifts, which may be due to the modifications in counter ions that are associated with hydroxyl, amino and carboxylic groups.

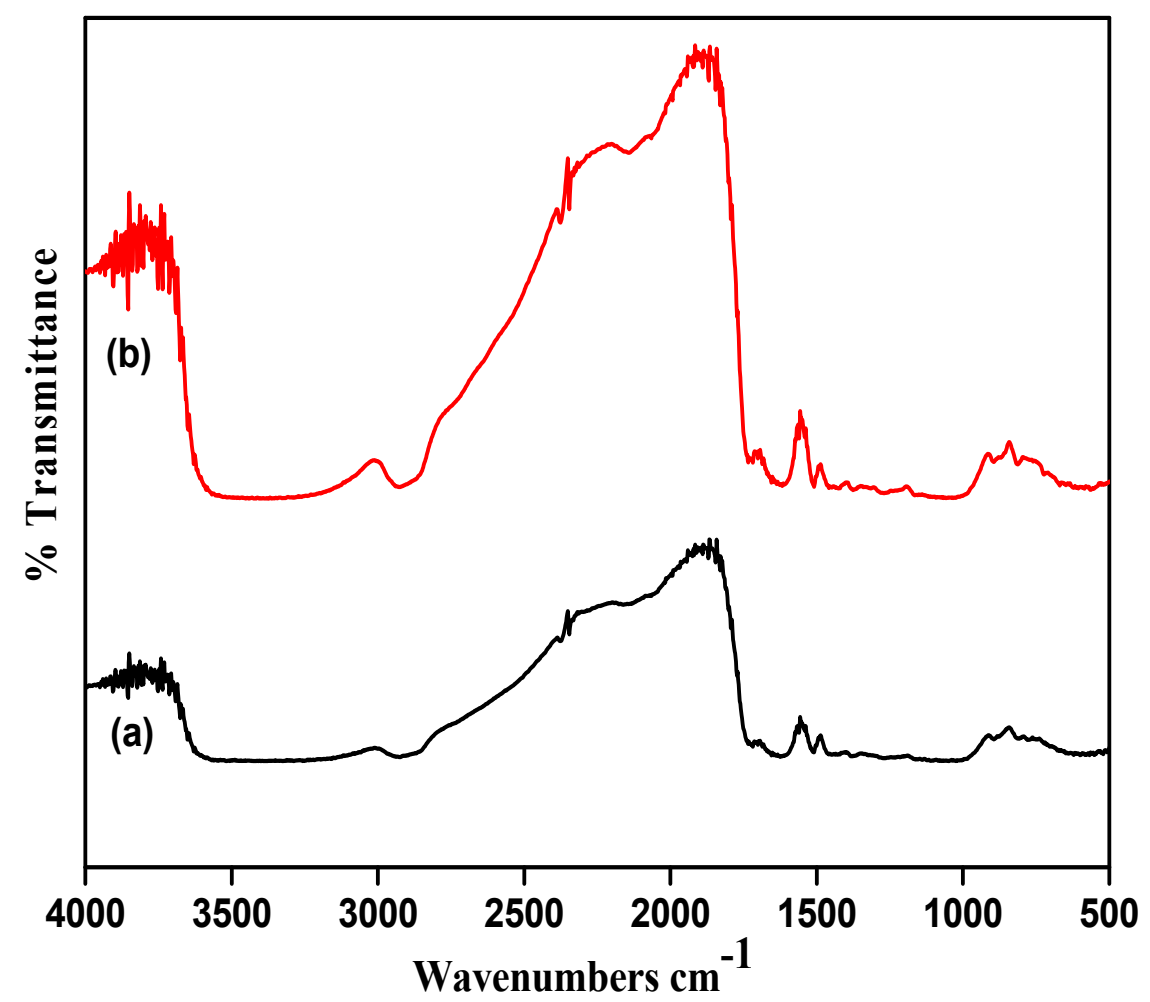

Figure 1. FTIR spectrum of (a) native PCP and (b) 2,4,6-trichlorophenol (TCP) loaded PCP. 


\subsubsection{SEM}

Figure 2 displays the SEM images of the PCP sorbent. As seen in Figure 2a natural pine cone shows significant surface with pores. It displays a flake type behavior with irregular surface structure with some agglomeration. In Figure $2 \mathrm{~b}$ at a higher magnification, the irregular surface containing pores are clearly visible in the biosorbent. This kind of surface morphology can help trapping and adsorption of molecules of TCP.
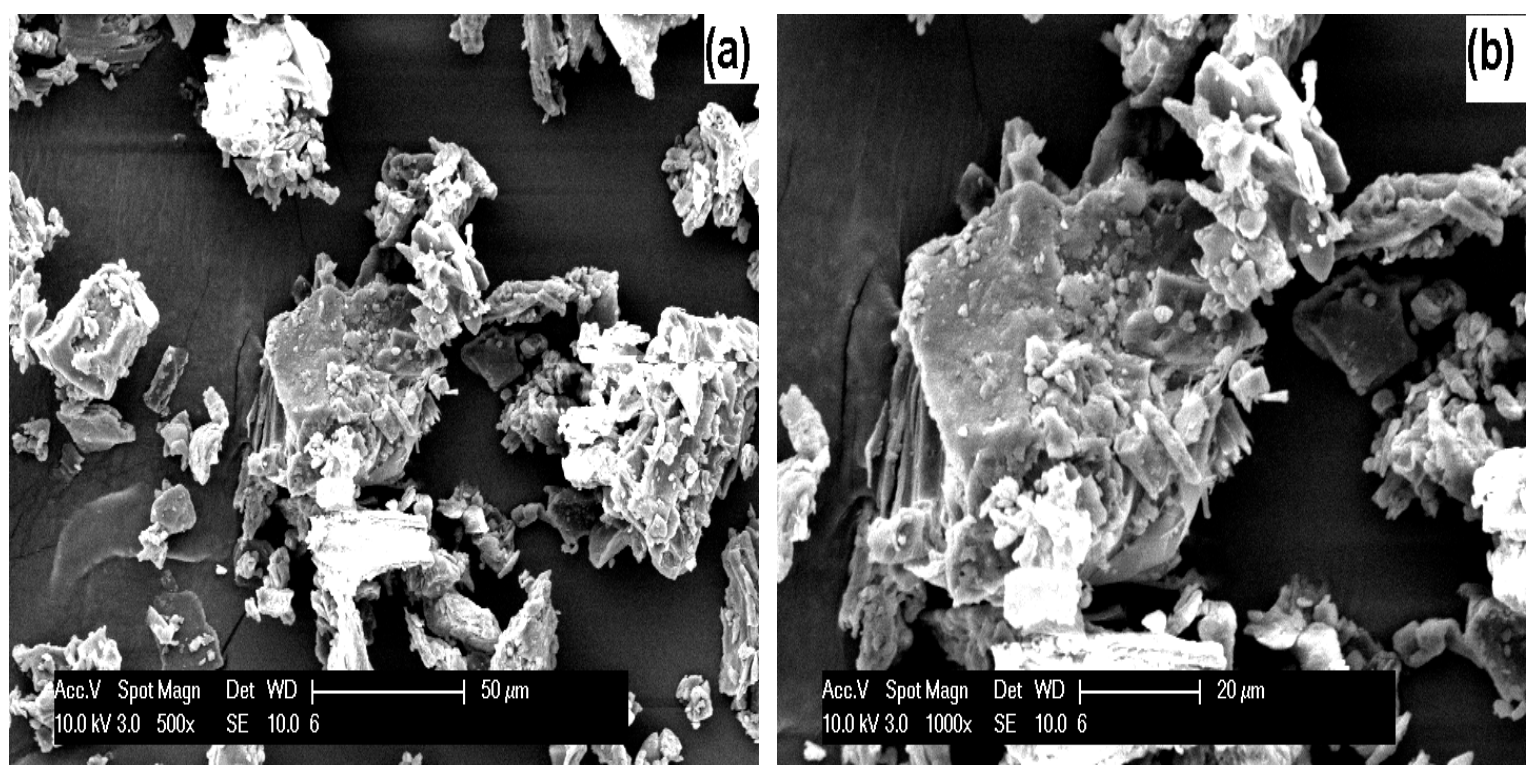

Figure 2. SEM of the PCP at (a) 500× and (b) $1000 \times$ magnification.

\subsubsection{XRD Analysis}

XRD patterns were recorded with the help of using Siemens D $5000 \mathrm{X}$-ray diffractometer at $40 \mathrm{kV}$ voltage and using $1.5406 \AA \mathrm{Cu} / \mathrm{K} \alpha$ radiation (figure not shown). The angle diffraction was varied in the range of 10 to $60^{\circ}$. The broad peak cellulose at $2 \theta=21.2-22.4^{\circ}$ confirms the amorphous nature of the present adsorbent.

\subsection{Investigation of Solution $p H$}

Biosorption capacity is greatly affected by the solution $\mathrm{pH}$. Its effect was therefore studied on the PCP uptake capacity by changing the solution $\mathrm{pH}$ range in 2-10. A strong correlation between the solution $\mathrm{pH}$ and the uptake of the TCP was noticed. As seen in Figure 3, the TCP uptake increases from $50.96 \mathrm{mg} / \mathrm{g}$ to $94.31 \mathrm{mg} / \mathrm{g}$ when the increased solution $\mathrm{pH}$ from 2 to 6 . A further increase in the solution $\mathrm{pH}$, however, lowers the biosorption capacity. Since the TCP is a weak acid with a dissociation constant ( $\mathrm{pKa}$ ) of 6.23 , the acidic $\mathrm{pH}$ below the $\mathrm{pKa}$ value favors TCP to remain un-dissociated, and the dispersion interactions predominate [20,35]. At superior $\mathrm{pH}$ values $(\mathrm{pH}>6)$, since chlorophenols are in the form of a salt which loses its negative charge easily, and hence becomes difficult to adsorb, resulting in a decrease in its biosorption [36]. At lower $\mathrm{pH}$ values, the protonated chlorophenols were more adsorbable than their ionized forms. The nature of the surface of the pine cone powder also affects the overall biosorption mechanism. Earlier, similar behavior was also observed the adsorption of chlophenols on other adsorbents, such as Acacia leucocephala bark [18], pine bark powder [20], activated carbon produced using palm empty fruit bunch, coconut husk, activated clay, coconut shell [37-40], and various agricultural wastes, e.g., sunflower seed hulls, pumpkin seed shells, walnut shells and peanut shells [21]. Therefore, all the remaining experiments were conducted at the optimum $\mathrm{pH}$ value of 6 . 


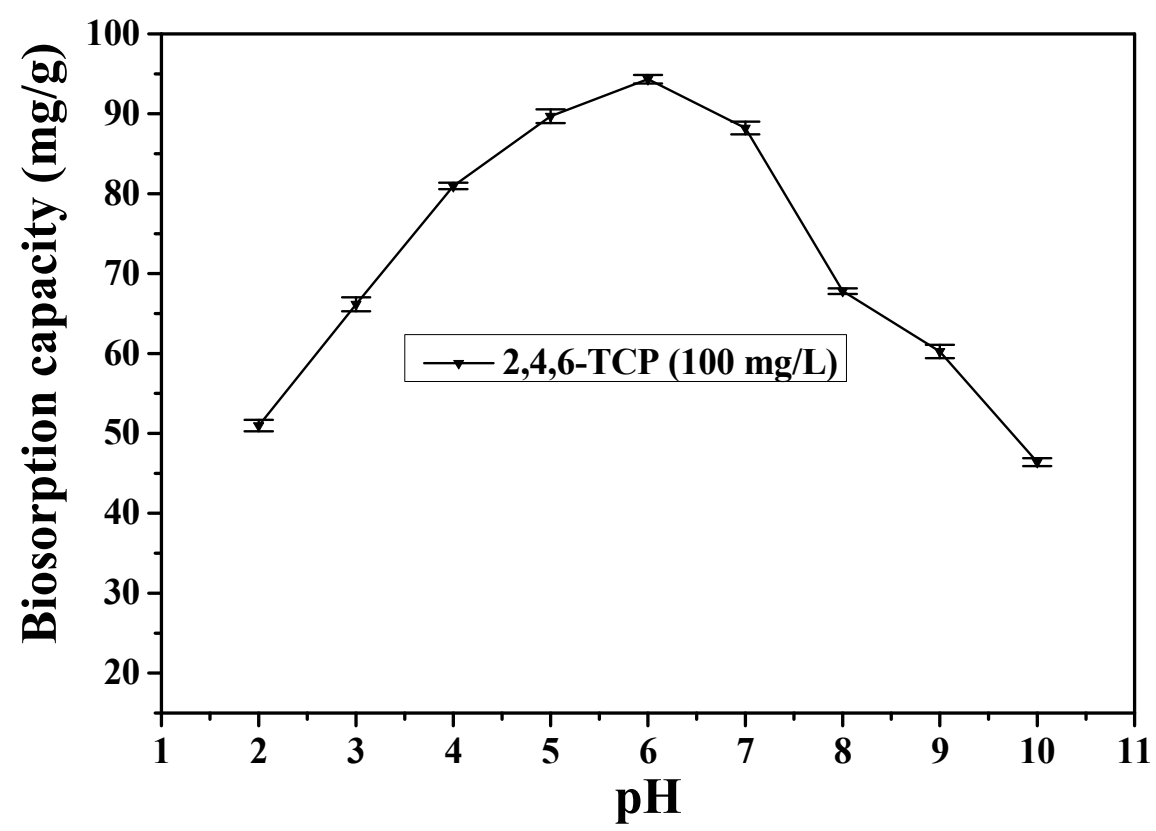

Figure 3. Dependence of TCP biosorption on solution $\mathrm{pH}$ at $30 \pm 1{ }^{\circ} \mathrm{C}\left(\mathrm{C}_{0}=100 \mathrm{mg} / \mathrm{L}\right.$, Contact time $=2 \mathrm{~h}$, Biosorbent dosage $=0.1 \mathrm{~g}$, Agitation rate $=200 \mathrm{rpm}$. The error bars are SD of triplicate runs.

\subsection{Influence of Sorbent Dosage}

Biosorbent dosage is one of the important parameters which determines the efficacy of the process of the biosorption. Therefore, the biosorption experiments were performed by changing the biosorbent dose from $0.05-0.8 \mathrm{~g}$ in $100 \mathrm{~mL}$ test solution with $100 \mathrm{mg} / \mathrm{L} \mathrm{TCP}$ concentration at optimum $\mathrm{pH} 6$ for $3 \mathrm{~h}$ at $30 \pm 1{ }^{\circ} \mathrm{C}$ to determine the effect of biosorbent dosage. As shown in Figure 4, the removal percentage of TCP was found to increase from 51.7 to $98.3 \%$ with increasing PCP dosage owing to enhanced active sites on the surface of the adsorbent, making TCP penetration easier into the active sites [20]. On the other hand, uptake capacity, which is the amount of TCP molecules adsorbed per unit PCP, considerably decreased. It can be attributed to the biosorbent agglomeration or interaction between sorbent atoms, thus decreasing the availability of active sorption sites [16,41]. Furthermore, above $0.5 \mathrm{~g} / \mathrm{L}$, there is hardly any enhancement in removal efficiency of TCP.

\subsection{Effect of 2,4,6-TCP Initial Concentration and Contact Time}

Contact time is another key parameter affecting the contaminant uptake by the biosorbent. The effect of agitation duration and the initial TCP concentration $(100-400 \mathrm{mg} / \mathrm{L})$ on the TCP uptake was carefully investigated at $30^{\circ} \mathrm{C}$. Figure 5 shows that the enhancement capacity with time and initial concentration. The uptake rate is initially fast until an equilibrium constant value is reached after $75 \mathrm{~min}$. of contact. The fast uptake rate at the beginning of biosorption was caused by the greater affinity of the interacting groups and availability of the external surface of the biosorbent. Figure 5 shows that the equilibrium uptake capacity $\left(q_{e}\right)$ increases from 82.69 to $230.83 \mathrm{mg} / \mathrm{g}$ as the TCP initial concentrations is increased from $100-400 \mathrm{mg} / \mathrm{L}$. Because higher initial concentration leads to greater mass transfer driving force, thus leading to higher TCP biosorption. Therefore, we fixed the contact time to $75 \mathrm{~min}$ for our batch experimental studies. 


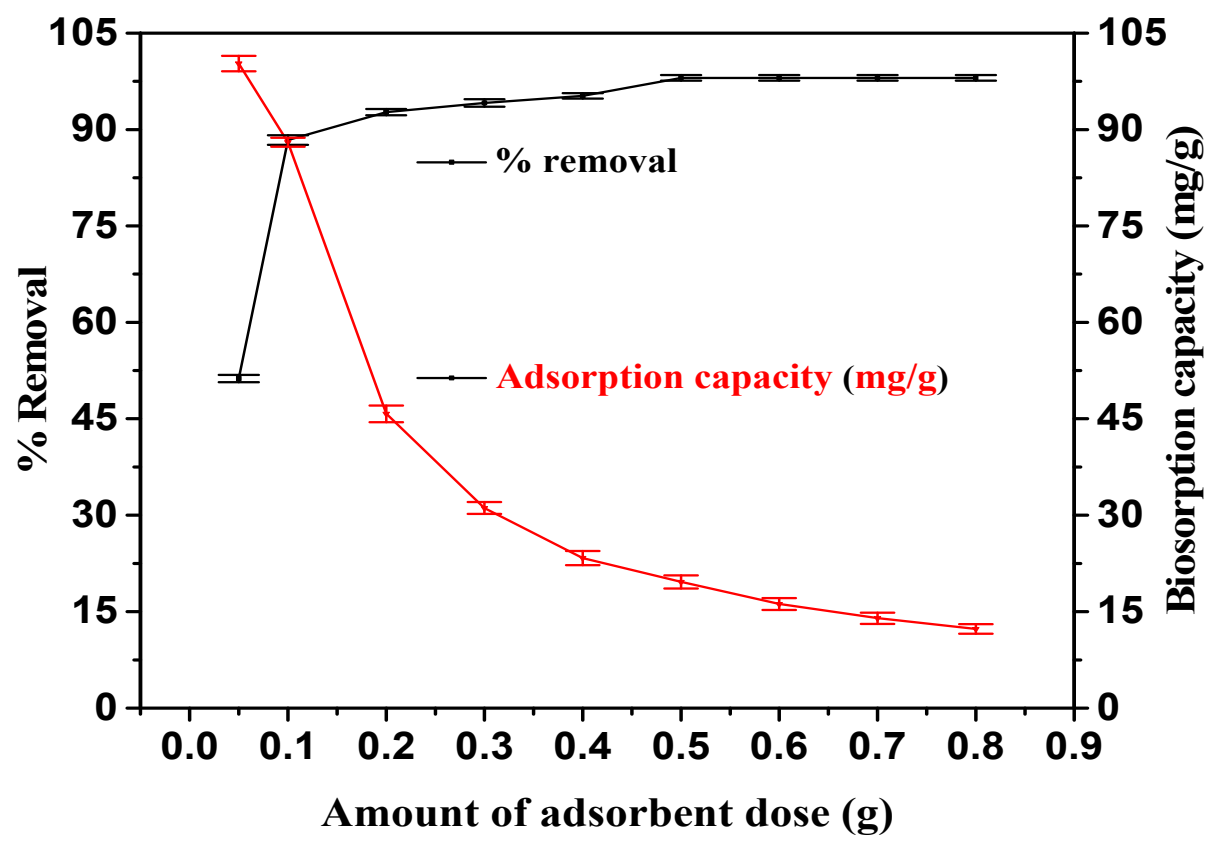

Figure 4. Dependence of TCP biosorption on the adsorbent dosage level at $30 \pm 1{ }^{\circ} \mathrm{C}\left(C_{0}=100 \mathrm{mg} / \mathrm{L}\right.$, Biosorbent dosage $=0.05-0.8 \mathrm{~g}$, Contact time $=3 \mathrm{~h}, \mathrm{pH}=6.0$. The error bars are SD of triplicate runs.

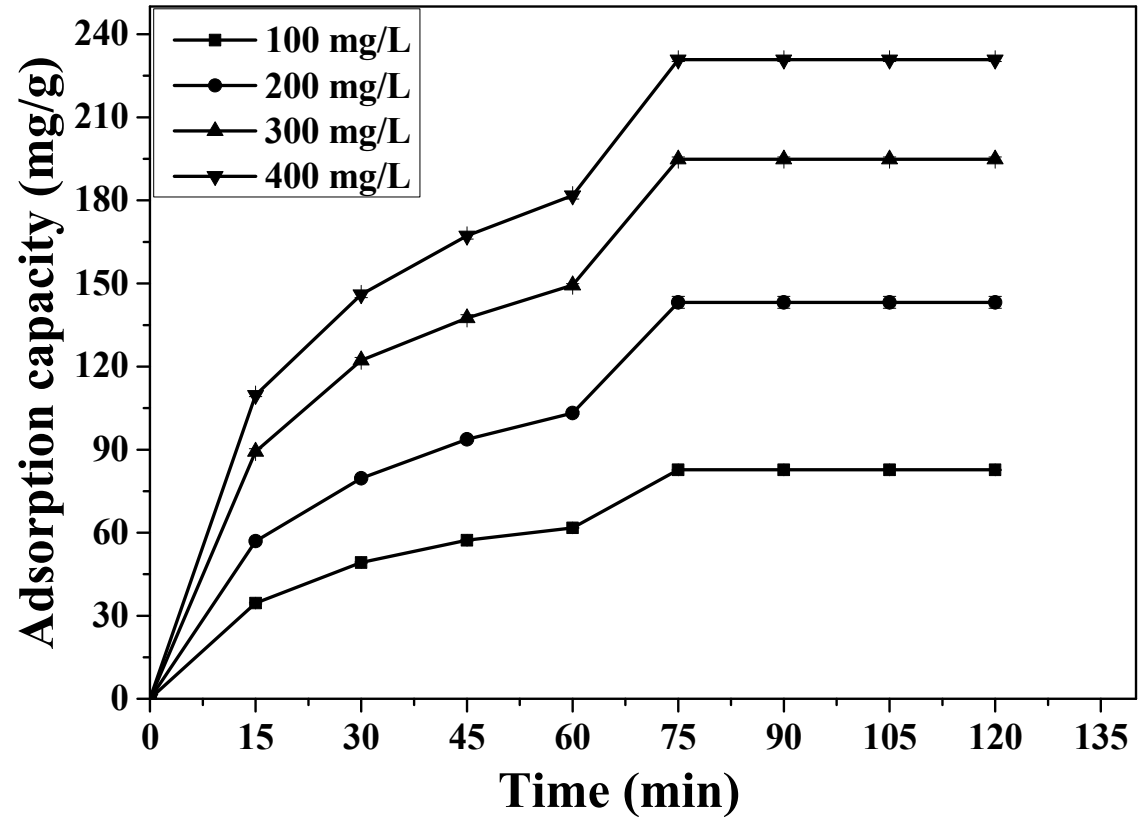

Figure 5. Dependence of TCP biosorpion on the contact time at $30 \pm 1{ }^{\circ} \mathrm{C}\left[(\boldsymbol{\square}) \mathrm{C}_{0}=100 \mathrm{mg} / \mathrm{L},(\bullet)\right.$ $C_{0}=200 \mathrm{mg} / \mathrm{L},(\boldsymbol{\Delta}) C_{0}=300 \mathrm{mg} / \mathrm{L},(\boldsymbol{\nabla}) C_{0}=400 \mathrm{mg} / \mathrm{L} ;$ Biosorbent dosage $=0.1 \mathrm{~g} ;$ Contact time $=2 \mathrm{~h}$, Agitation rate $=200 \mathrm{rpm} ; \mathrm{pH}=6.0$ ]. The error bars are $\mathrm{SD}$ of triplicate runs.

A wide range of equilibrium contact time for the TCP adsorption has been reported in the literature. Using commercial grade activated carbon produced from coconut shell-based, Radhika et al. found that the equilibrium time varied in the range of 60-210 min when the initial contaminant concentration was varied from 10 to $100 \mathrm{mg} / \mathrm{L}$ [40]. Using calcined $\mathrm{Mg} / \mathrm{Al}-\mathrm{CO}_{3}$ layered double hydroxide (CLDH), the equilibrium adsorption time of $180 \mathrm{~min}$ was reported for $C_{0}=25-400 \mathrm{mg} / \mathrm{L}$ [42]. On the other hand, 400 min was required for the removal of 2,4,6-TCP using PU@PDA@MSNs sponge for lower initial contaminant concentrations varying from 50 to $100 \mathrm{mg} / \mathrm{L}$ [43]. Denizli et al. also stated $240 \mathrm{~min}$ of equilibrium contact time for $C_{0}=500 \mathrm{mg} / \mathrm{L}$ [44]. Kumar et al. reported $180 \mathrm{~min}$ of equilibrium 
contact time for the 2,4,6-TCP biosorption on Acacia leucocephala bark for $C_{0}=50-200 \mathrm{mg} / \mathrm{L}$ [2]. Using activated carbon produced from oil palm empty fruit bunch, Tan et al. reported the agitation time of $1 \mathrm{~h}$ for the sorption of TCP for $C_{0}=25-150 \mathrm{mg} / \mathrm{L}$, and 5-6 h for $C_{0}=200-250 \mathrm{mg} / \mathrm{L}$ [45]. In another study, $120 \mathrm{~min}$ was required for the removal of 2,4,6-TCP using pine bark powder for initial concentrations of $100-400 \mathrm{mg} / \mathrm{L}[20]$.

\subsection{Biosorption Kinetics}

The biosorption kinetics governs the uptake rate of the contaminant from aqueous media and is therefore crucial in determining the residence time for the design of continuous large-scale adsorption reactors. Several models of varied complexity have been proposed to predict the contaminant uptake rate by the adsorbent. However, besides commonly used PFO, PSO models, Elovich and IPD (intraparticle diffusion) models are also used here to explain the biosorption kinetics [46,47]. The PFO kinetic model is mathematically expressed as [48]:

$$
\log \left(q_{e}-q_{t}\right)=-\frac{k_{1}}{2.303} t+\log q_{e}
$$

where the rate constant $k_{1}(1 / \mathrm{min})$ can be evaluated using the slope of time versus $\log \left(q_{e}-q_{t}\right)$ plot. Another commonly used model, the PSO kinetic model, can be stated as [49],

$$
\frac{t}{q_{t}}=\frac{1}{q_{e}} t+\frac{1}{k_{2} q_{e}^{2}}
$$

Plotting $t$ versus $t / q_{t}$ yields $1 / q_{e}(\mathrm{~g} / \mathrm{mg})$ as the slope while the PSO rate constant $k_{2}(\mathrm{~g} / \mathrm{mg}$ min) can be evaluated from the plot intercept. The rate constants of both kinetic models and their correlation coefficients are presented in Table 2. In addition, $q_{e}(\exp )$ are also shown for comparison with corresponding predicted values. The PSO shows better agreement between experimental values and model predictions of $q_{e}$ in the range of initial TCP concentration $\left(C_{0}=100-400 \mathrm{mg} / \mathrm{L}\right)$ considered in the present study. The same trend is also seen for the correlation coefficients $\left(R^{2}\right)$. This confirms the superiority of the PSO kinetics as compared to the PFO kinetics in predicting the biosorption of TCP using the pine cone.

Elovich equation is also used to model the contaminant uptake rate. Without suggesting any clear mechanism governing the adsorbent and adsorbent interaction, the model uses the assumption that the adsorbent surfaces are energetically heterogeneous. Elovich equation's linear form can be written as [50],

$$
q_{t}=\frac{1}{b} \ln t+\frac{\ln (a b)}{b}
$$

where the parameter ' $a$ ' denotes the initial biosorption rate while the parameter ' $b$ ' (g/mg) is related to the extent of surface coverage and the chemisorption activation energy. The plot of $\ln t$ versus $q_{t}$ yields $(1 / b)$ as the slope and $\ln (a b) / b$ as the intercept. From Table 2, it can be seen that the calculated $q_{e}$ values of Elovich model does not show good agreement with experimental equilibrium values. 
Table 2. Kinetic rate constants for biosorption of TCP onto PCP. The error bars represent mean \pm SD of each triplicate value.

\begin{tabular}{|c|c|c|c|c|}
\hline \multirow{2}{*}{ Parameter } & \multicolumn{4}{|c|}{ Initial Concentration of TCP $(\mathrm{mg} / \mathrm{L})$} \\
\hline & 100 & 200 & 300 & 400 \\
\hline \multicolumn{5}{|c|}{ Pseudo-first-order-kinetic model } \\
\hline$q_{(e, \exp )}(\mathrm{mg} / \mathrm{g})$ & $82.69 \pm 0.35$ & $143.20 \pm 3.71$ & $194.84 \pm 1.51$ & $230.83 \pm 0.16$ \\
\hline$q_{(e, c a l)}(\mathrm{mg} / \mathrm{g})$ & $60.80 \pm 0.89$ & $108.80 \pm 5.66$ & $133.25 \pm 1.84$ & $159.22 \pm 0.54$ \\
\hline$k_{1}(1 / \mathrm{min})$ & $0.018 \pm 0.0004$ & $0.017 \pm 0.0004$ & $0.018 \pm 0.0001$ & $0.019 \pm 0.001$ \\
\hline$R^{2}$ & 0.9812 & 0.9927 & 0.9815 & 0.9945 \\
\hline$\Delta q_{t}(\%)$ & 52.68 & 50.89 & 59.64 & 57.44 \\
\hline$x^{2}$ & 74.21 & 110.23 & 270.71 & 292.10 \\
\hline \multicolumn{5}{|c|}{ Pseudo-second-order-kinetic model } \\
\hline$q_{(e, c a l)}(\mathrm{mg} / \mathrm{g})$ & $83.80 \pm 1.06$ & $142.28 \pm 4.58$ & $191.09 \pm 2.09$ & $232.64 \pm 5.41$ \\
\hline$k_{2}(\mathrm{~g} / \mathrm{mg} / \mathrm{min})$ & $0.00056 \pm 2.85 \times 10^{-5}$ & $0.00030 \pm 3.83 \times 10^{-5}$ & $0.00030 \pm 4.91 \times 10^{-6}$ & $0.00024 \pm 9.22 \times 10^{-6}$ \\
\hline $\mathrm{R}^{2}$ & 0.9994 & 0.9992 & 0.9998 & 0.9994 \\
\hline$\Delta q_{t}(\%)$ & 0.52 & 1.02 & 0.54 & 1.14 \\
\hline$x^{2}$ & 0.01 & 0.02 & 0.01 & 0.05 \\
\hline \multicolumn{5}{|c|}{ Elovich equation } \\
\hline$q_{(e, c a l)}(\mathrm{mg} / \mathrm{g})$ & $100.01 \pm 3.45$ & $170.88 \pm 12.30$ & $203.64 \pm 1.32$ & $244.16 \pm 4.31$ \\
\hline$(1 / b) \ln (a b)(\mathrm{mg} / \mathrm{g})$ & $18.79 \pm 1.59$ & $33.84 \pm 5.65$ & $26.72 \pm 0.99$ & $31.09 \pm 1.03$ \\
\hline $1 / b(\mathrm{mg} / \mathrm{g})$ & $19.83 \pm 0.45$ & $33.47 \pm 1.62$ & $43.21 \pm 0.09$ & $52.03 \pm 0.80$ \\
\hline $\mathrm{R}^{2}$ & 0.9963 & 0.9993 & 0.9943 & 0.9999 \\
\hline$\Delta q_{t}(\%)$ & 8.38 & 10.80 & 7.55 & 6.72 \\
\hline$x^{2}$ & 1.07 & 2.82 & 2.14 & 2.04 \\
\hline \multicolumn{5}{|c|}{ Weber-Morris } \\
\hline$q_{(e, c a l)}(\mathrm{mg} / \mathrm{g})$ & $63.43 \pm 0.33$ & $105.01 \pm 1.09$ & $152.38 \pm 0.83$ & $184.73 \pm 2.26$ \\
\hline$k_{i d}$ & $7.07 \pm 0.15$ & $12.01 \pm 0.58$ & $15.42 \pm 0.06$ & $18.65 \pm 0.27$ \\
\hline $\mathrm{C}$ & $8.56 \pm 0.92$ & $11.87 \pm 3.43$ & $32.80 \pm 0.63$ & $40.13 \pm 0.14$ \\
\hline $\mathrm{R}^{2}$ & 0.9758 & 0.9907 & 0.9749 & 0.9885 \\
\hline$\Delta q_{t}(\%)$ & 47.49 & 49.58 & 40.35 & 40.23 \\
\hline$x^{2}$ & 86.34 & 183.30 & 111.66 & 136.66 \\
\hline
\end{tabular}

\subsection{Intraparticle Diffusion Model}

This model evaluates the relative significance of the intra-particle diffusion in the mass transport of the solute [51]. According to this model, the time dependence of the concentration of the adsorbate is mathematically described as,

$$
q_{t}=k_{i d} \sqrt{t}+C
$$

where $k_{i d}$ is the slope $\left(\mathrm{mg} / \mathrm{g} \cdot \mathrm{min}^{1 / 2}\right)$ of $\sqrt{t}$ versus $q_{t}$ plot while the $\mathrm{y}$-intercept $C$ is a thickness of the boundary layer. The computed $k_{i d}$ values are shown in Table 2. If Equation (9) yields a linear trend, passing through the origin, then the intraparticle diffusion is the predominant rate limiting step. As seen in Table 2, the intercept ranges from 8 to 40 . Therefore, intra-particle diffusion model is not valid in this case. A large intercept shows that the adsorption mainly takes place on the biosorbent surface, and the mass transport is controlled by external mass transport resistance throughout the movement of the solute from the liquid phase to the external surface of the biosorbent.

Figure 6a-d compares the experimental data and model predictions for the TCP concentrations varying from 100 to $400 \mathrm{mg} / \mathrm{L}$. The PFO, PSO, intraparticle diffusion and Elovich kinetic equations are considered in the comparison. It is clear from the figures that the predictions of the PSO kinetic model show an excellent agreement with the experimental data. Clearly, the PFO kinetics fail to provide an adequate description of the biosorption of TCP onto PCP. The results fitted with different kinetic models of TCP adsorption on PCP, their corresponding regression $\left(\mathrm{R}^{2}\right)$, Chi-square $\left(\chi^{2}\right)$ and $\Delta q(\%)$ values are listed in Table 2. The value of $R^{2}$ for the PSO was greater than 0.999 , which was much closer to unity than those of the PFO, Elovich, and Weber-Morris models. Using PSO, the calculated $\left(q_{e, c a l}\right)$ values show excellent fit with the experimental values $\left(q_{t, \text { exp }}\right)$. This was evident from the Chi-square $\left(\chi^{2}\right)$ and $\Delta q(\%)$ values, which ranged between $0.01-0.05$ for the case of the former and $0.52-1.14 \%$ for 
the case of the latter. Thus, the investigational results indicate that the PSO appears to be a better fit for TCP biosorption on PCP, which is similar to the recent investigations, have shown that the kinetics of TCP adsorption onto other adsorbents also followed PSO kinetic models [21,42,52].
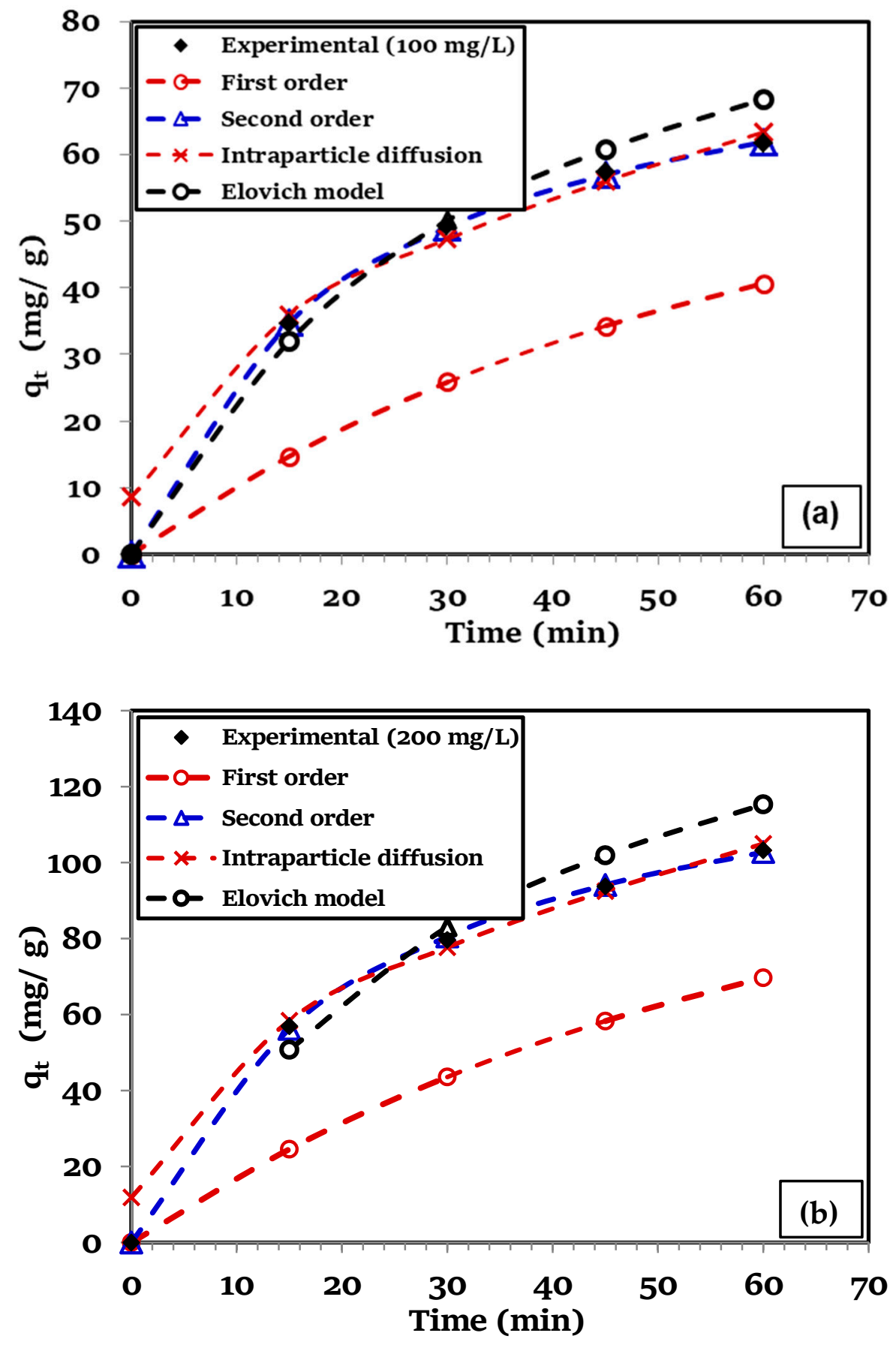

Figure 6. Cont. 

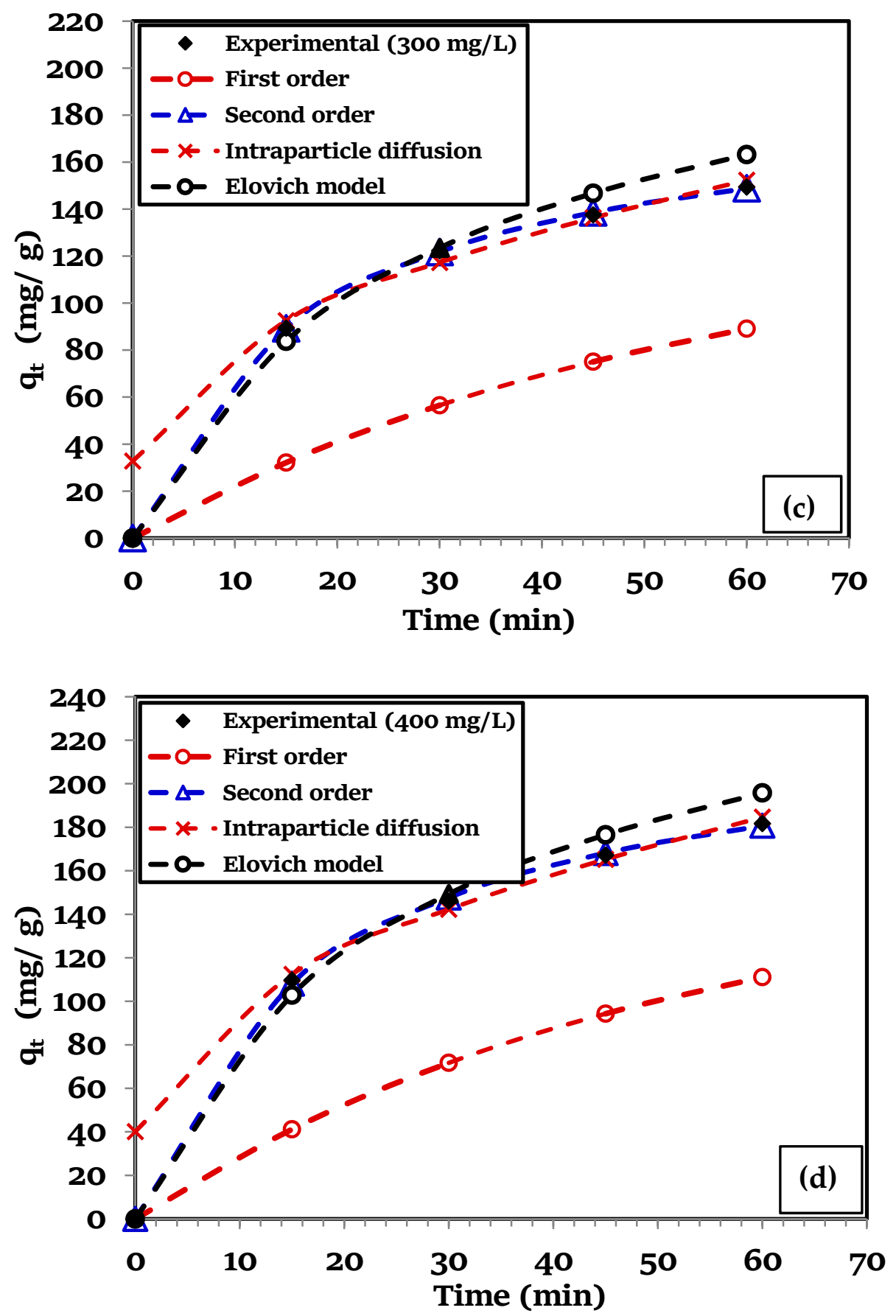

Figure 6. Comparison of experimental and calculated values obtained from the PFO, PSO, intraparticle diffusion and Elovich kinetic models (a-d).

\subsection{Biosorption Isotherm Models}

The adsorption equilibrium isotherms play a key role in the biosorption system design. It shows the affinity of the biosorbent towards the solute and how the solute ions are dispersed between the liquid solution and the biosorbent surface in equilibrium state. In this study, we focus our attention on four different empirical models.

The Langmuir isotherm equation general form can be expressed as [53],

$$
\left(\frac{1}{q_{e}}\right)=\frac{1}{K_{L} q_{m}}\left(\frac{1}{C_{e}}\right)+\frac{1}{q_{m}}
$$


In this equation $q_{e}$ is the solute amount adsorbed per unit biosorbent mass $(\mathrm{mg} / \mathrm{g}), q_{m}$ is the monolayer biosorption capacity $(\mathrm{mg} / \mathrm{g}), C_{e}$ is the equilibrium concentration of the solute in solution $(\mathrm{mg} / \mathrm{L})$, and $K_{L}(\mathrm{mg} / \mathrm{L})$ is the Langmuir equilibrium constant. Plotting $1 / q_{e}$ versus $1 / C_{e}$ yields values for both $q_{m}$ and $K_{L}$.

An important aspect of the Langmuir isotherm is often indicated as a dimensionless parameter, $R_{L}$, which can be expressed as [54],

$$
R_{L}=\frac{1}{1+K_{L} C_{0}}
$$

$R_{L}$ shows the nature of the biosorption process. For a favorable adsorption process, $0<R_{L}<1$, unfavorable for $R_{L}>1$, linear for $R_{L}=1$, and irreversible for $R_{L}=0$.

Freundlich isotherm model, correlating heterogeneous surface containing binding sites to their different energies, is given as [55],

$$
q_{\mathbf{e}}=K_{F} C_{e}^{\frac{1}{n}}
$$

where the parameter $K_{F}\left((\mathrm{mg} / \mathrm{g})(\mathrm{L} / \mathrm{mg})^{1 / n}\right)$ represents 'relative biosorption capacity' while the parameter $(1 / n)$ denotes 'adsorption intensity'. For values of parameter $n$ greater than unity, sorption is favorable. The linearized form of Equation (10) is:

$$
\ln q_{e}=\left(\frac{1}{n}\right) \ln C_{e}+\ln K_{F}
$$

This model accounts for the interactions between the adsorbent and adsorbate molecules [56]. Mathematically, it is represented as:

$$
q_{e}=\left(\frac{R T}{b_{T}}\right) \ln \left(A C_{e}\right)
$$

where isotherm parameter $A(\mathrm{~L} / \mathrm{g})$ is the binding constant that corresponds to the maximum binding energy, $R=8.314 \mathrm{~J} / \mathrm{mol} \mathrm{K}$ is the universal gas constant, $T(\mathrm{~K})$ is the temperature and the factor $R T / b_{T}$ $(\mathrm{J} / \mathrm{mol})$ is a constant related to heat of sorption.

In order to improve greater insight of the biosorption process, Dubinin-Radushkevich isotherm has also been utilized to model the present equilibrium data [57]. It is represented as,

$$
q_{e}=q_{s} \exp \left(-B \varepsilon^{2}\right)
$$

where the parameter $B$ is a measure of the sorption energy, and $q_{s}$ is the D-R monolayer capacity $(\mathrm{mg} / \mathrm{g})$. The $\varepsilon$ parameter in the above equation is known as Polanyi potential, and is defined by,

$$
\varepsilon=R T \ln \left[1+\frac{1}{C_{e}}\right]
$$

Using the parameter ' $B$ ' in Equation (15), the mean free adsorption energy $(E)$ per adsorbate molecule can be computed as follows,

$$
E=\frac{1}{\sqrt{2 B}}
$$

A plot of $\ln \left(q_{e}\right)$ versus $\varepsilon^{2}$ will enable the evaluation of isotherm parameter $q_{s}$ and $E$. The parameter $E$ characterizes the nature of the biosorption process in the present investigation. For biosorption by ion exchange, the value of $E$ usually lies between 8 and $16 \mathrm{~kJ} / \mathrm{mol}$, while it is less than $8 \mathrm{~kJ} / \mathrm{mol}$ for the case of physical adsorption. Correlation coefficients, parameter values, normalized standard deviation $(\Delta q(\%))$ and Chi-square $\left(\chi^{2}\right)$ for all four isotherms, i.e., Langmuir, Freundlich, Temkin and D-R are presented in Table 3 for the comparison. The predictions of all the four isotherm models are compared with the experimental data in Figure 7. It is evident that the Langmuir isotherm model shows better agreement with the experimental sorption data as compared to Freundlich, D-R and Temkin isotherm 
models. For the Langmuir isotherm, higher $\mathrm{R}^{2}(0.998)$, lower $\Delta q(3.84 \%)$, and lower Chi-square $\left(\chi^{2}\right)$ value (0.90) were obtained in the present study.

Table 3. Isotherm Parameters for biosorption of TCP onto PCP.

\begin{tabular}{cccccc}
\hline Isotherms & \multicolumn{1}{c}{ Constants } & & $\mathbf{R}^{\mathbf{2}}$ & $\boldsymbol{\Delta} \boldsymbol{q}_{\boldsymbol{e}} \mathbf{( \% )}$ & $\boldsymbol{\chi}^{\mathbf{2}}$ \\
\hline Langmuir & $q_{m}(\mathrm{mg} / \mathrm{g})$ & $b(\mathrm{~L} / \mathrm{mg})$ & & & \\
& 243.90 & 0.009 & 0.9989 & 3.84 & 0.90 \\
\hline Freundlich & $K_{F}\left((\mathrm{mg} / \mathrm{g})(\mathrm{L} / \mathrm{mg})^{1 / n}\right)$ & $\mathrm{n}$ & & & \\
& 3.229 & 1.245 & 0.9931 & 5.62 & 1.98 \\
\hline D-R model & $q_{s}(\mathrm{mg} / \mathrm{g})$ & $E(\mathrm{~kJ} / \mathrm{mol})$ & & & \\
& $8.22 \times 10^{-3}$ & 8.28 & 0.9965 & 3.95 & 1.09 \\
\hline Temkin & $A(\mathrm{~L} / \mathrm{g})$ & $b_{T}$ & & & \\
& 0.16 & 65.78 & 0.9451 & 32.21 & 112.34 \\
\hline
\end{tabular}

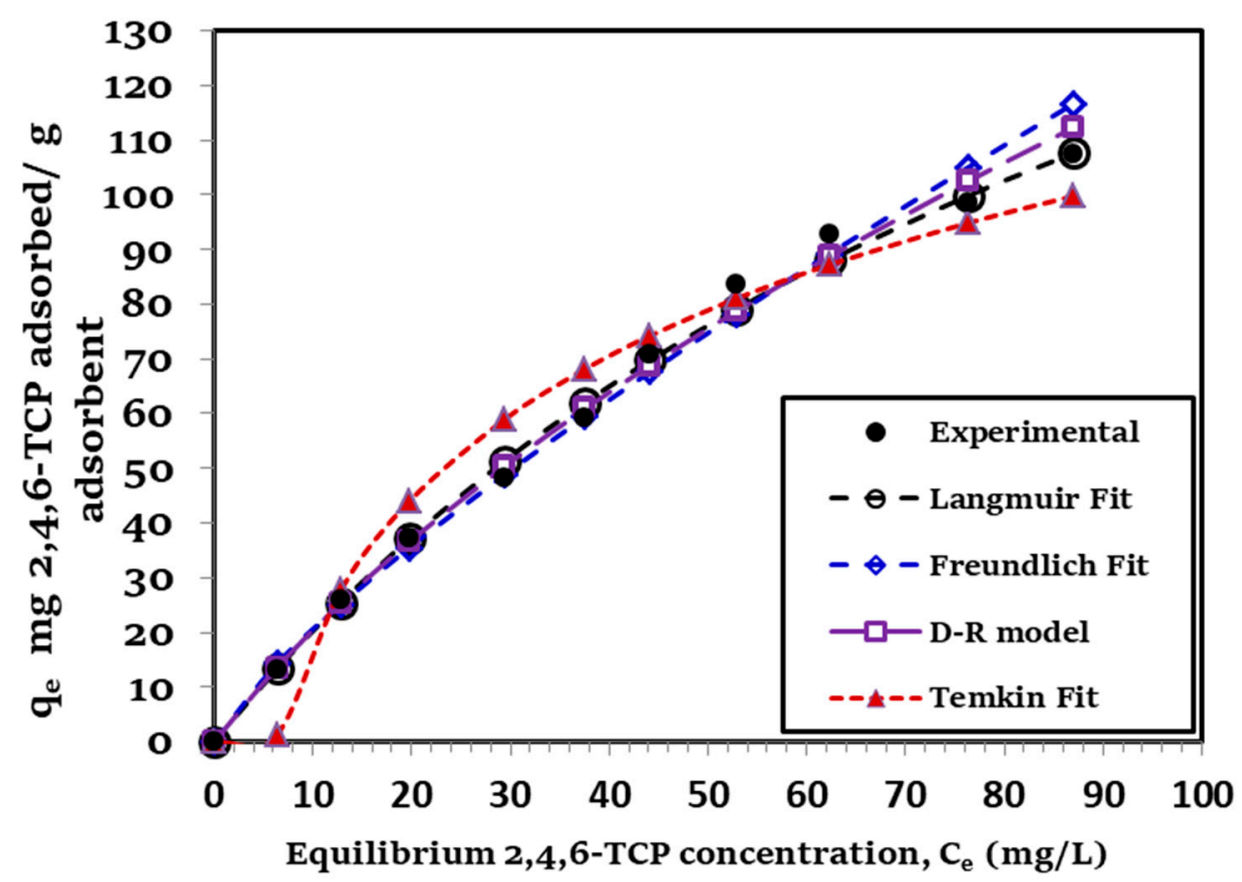

Figure 7. Comparison of experimental and theoretical adsorption parameter values obtained from the Langmuir, Freundlich, D-R and Temkin isotherm models.

\subsection{2,4,6-TCP onto Pine Cone Powder (PCP) Biosorption Mechanism}

The FTIR graph (Figure 1) reveals the existence of organic functional groups such as hydroxyl $(-\mathrm{OH})$, amino $\left(-\mathrm{NH}_{2}\right)$ and carboxylic groups $(-\mathrm{COOH})$ on the surface of the biosorbent $(\mathrm{PCP})$. Clearly, the functional groups at PCP shift their positions due to the biosorption of TCP. This can be predictable to the chemical interaction between adsorbate with surface functional groups of biosorbent. Moreover, the kinetic and isotherm experimental data prove that the biosorption of TCP involved chemical interaction and electrostatic interactions between the aqueous phase and biosorption sites.

\subsection{Comparison of PBP with other Adsorbents}

The comparison of the uptake capacities of several adsorbents reported in the literature is made here. Clearly, PCP is a superior adsorbent for the removal of TCP as compared to other reported adsorbents (Figure 8). Its uptake capacity is found to be $243.90 \mathrm{mg} / \mathrm{g}$, which is higher than most of other agro-waste-based adsorbent materials [2,20,37-40,42,43,45,58-61]. This clearly establishes the efficacy of the PCP as a cheap, abundant and efficient biosorbent for the removal of TCP from an aqueous 
medium that do not require regeneration for the cost-effectiveness of the present biosorption-based separation process.

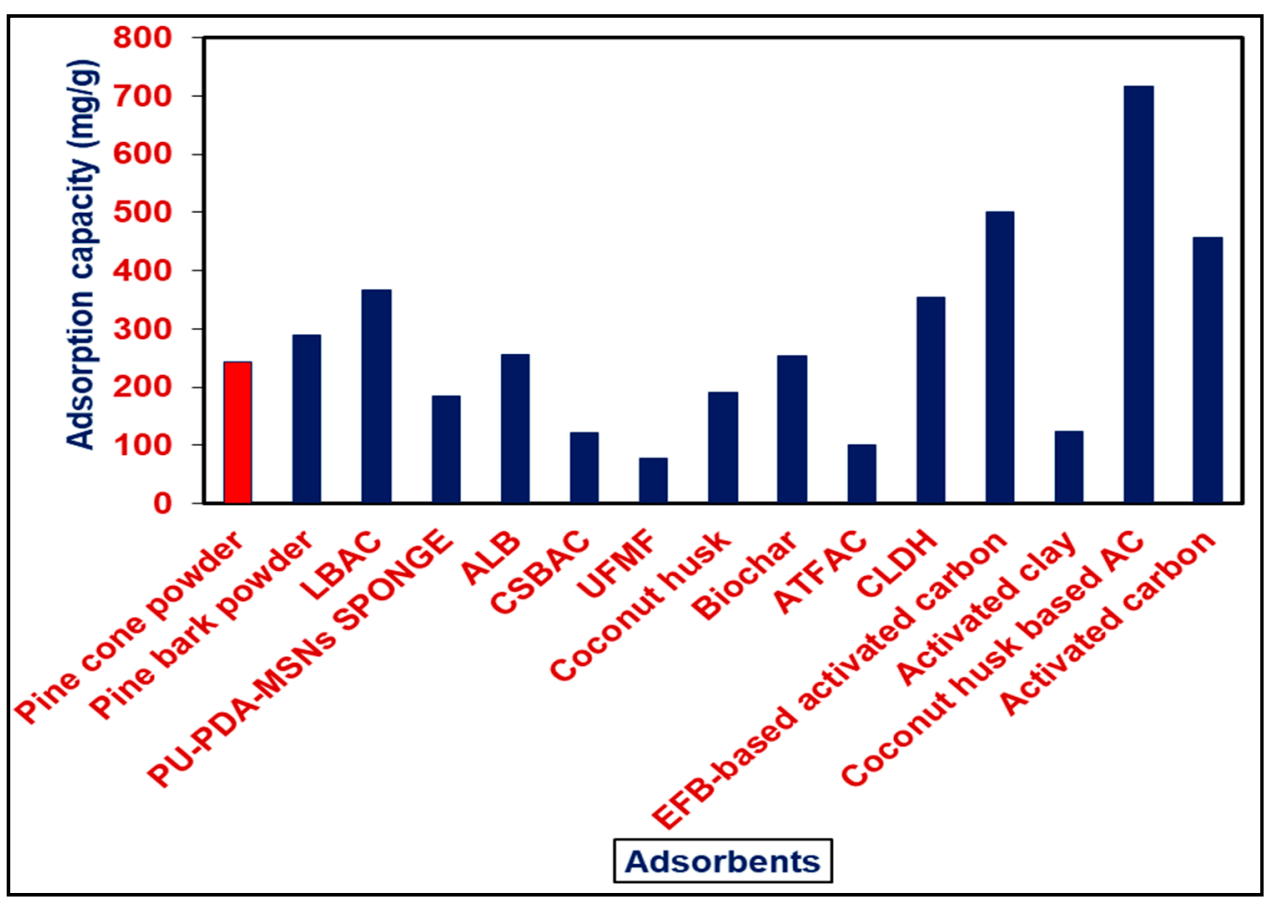

Figure 8. Comparison of maximum monolayer uptake capacities of various adsorbents for TCP.

\section{Conclusions}

We investigated the biosorption of TCP onto PCP, an untreated agro-waste material. The biosorption process was influenced by solution $\mathrm{pH}$, the time of contact, biosorbent dosage, and the initial TCP concentration. Moreover, the biosorption process was fast as the equilibrium was achieved in $75 \mathrm{~min}$ of agitation time. The solution $\mathrm{pH}$ of 6 was found to be optimal. The removal efficacy of TCP initially improved with an increase in the biosorbent dosage before becoming almost constant when $0.3 \mathrm{~g}$ PCP in $100 \mathrm{~mL}$ solution was used. With an increase in the PCP dosage however, the adsorption capacity gradually decreased. The second order kinetic model best represents the sorption kinetics. Several isotherm models, e.g., Dubinin-Radushkevich, Freundlich, Langmuir, and Temkin were used to describe the equilibrium data obtained in the present investigation. The maximum uptake biosorption capacity of $243.90 \mathrm{mg} / \mathrm{g}$ at $30 \pm 1{ }^{\circ} \mathrm{C}$ was predicted by the Langmuir model. Clearly, the PCP can be used as a cost-effective, eco-friendly and easily available biosorbent for the removal of high concentrations of TCP from contaminated wastewater.

Author Contributions: N.S.K. performed all the experiments and characterization tests as well as wrote the manuscript; A.M.P., M.S. and M.I.A.-H. carried out the literature review and proofread; M.A. and N.S.K. analyzed the data, finalized the paper and N.S.K. was the main corresponding author during the review process.

Funding: The Researchers Supporting Project at King Saud University Project No (RSP-2019/42).

Acknowledgments: The King Saud University authors would like to thank the Researchers Supporting Project, RSP-2019/42, King Saud University, Riyadh, Saudi Arabia for the financial support.

Conflicts of Interest: The author declares that there is no conflict of interest regarding this publication.

\section{References}

1. Achard, C.; Jaoui, M.; Schwing, M.; Rogalski, M. Aqueous solubilities of phenol derivatives by conductivity measurements. J. Chem. Eng. Data 1996, 41, 504-507. [CrossRef] 
2. Kumar, N.S.; Woo, H.S.; Min, K. Equilibrium and kinetic studies on biosorption of 2,4,6-trichlorophenol from aqueous solutions by Acacia leucocephala bark. Colloids Surf. B Biointerfaces 2012, 94, 125-132. [CrossRef] [PubMed]

3. Chen, M.; Tang, R.; Fu, G.; Xu, B.; Zhu, P.; Qiao, S.; Chen, X.; Xu, B.; Qin, Y.; Lu, C. Association of exposure to phenols and idiopathic male infertility. J. Hazard. Mater. 2013, 250, 115-121. [CrossRef] [PubMed]

4. Zhong, W.; Wang, D.; Xu, X. Phenol removal efficiencies of sewage treatment processes and ecological risks associated with phenols in effluents. J. Hazard. Mater. 2012, 217, 286-292. [CrossRef] [PubMed]

5. Zgola-Grzeskowiak, A.; Grzeskowiak, T.; Rydlichowski, R.; Lukaszewski, Z. Determination of nonylphenol and short-chained nonylphenol ethoxylates in drain water from an agricultural area. Chemosphere 2009, 75, 513-518. [CrossRef] [PubMed]

6. Michalowicz, J.; Duda, W. Phenols-sources and toxicity. Pol. J. Environ. Stud. 2007, 16, 347-362.

7. Marianna, C. Sources and transformations of chlorophenols in the natural environment. Sci. Total Environ. 2004, 322, 21-39.

8. Agency for Toxic Substances and Disease Registry (ATSDR). Toxicological Profile for 2,4,6-Trichlorophenol; U.S. Public Health Service, U.S. Department of Health and Human Services: Atlanta, GA, USA, 1990.

9. Kurian, M.; Babu, R. Iron aluminium mixed pillared montmorillonite and the rare earth exchanged analogues as efficient catalysts for phenol oxidation. J. Environ. Chem. Eng. 2013, 1, 86-91. [CrossRef]

10. McAllister, K.A.; Lee, H.; Trevors, J.T. Microbial degradation of pentachlorophenol. Biodegradation 1996, 7, 1-40. [CrossRef]

11. Oh, C.G.; Ahn, J.H.; Ihm, S.K. Adsorptive removal of phenolic compounds by using hypercrosslinked polystyrenic beads with bimodal pore size distribution. Reac. Funct. Polym. 2003, 57, 103-111. [CrossRef]

12. Kumar, N.S.; Subbaiah, M.V.; Reddy, A.S.; Krishnaiah, A. Biosorption of phenolic compounds from aqueous solutions onto chitosan-abrus precatorius blended beads. J. Chem. Tech. Biotechnol. 2009, 84, 972-981. [CrossRef]

13. Rama Rao, K.; Sahu, J.N.; Jayakumar, N.S. Optimal isotherm parameters for phenol adsorption from aqueous solutions onto coconut shell based activated carbon: Error analysis of linear and non-linear methods. J. Taiwan Inst. Chem. Eng. 2017, 80, 472-487.

14. Siva Kumar, N.; Boddu, V.M.; Krishnaiah, A. Biosorption of phenolic compounds by Trametes versicolor polyporus fungus. Adsorpt. Sci. Technol. 2009, 27, 31-46. [CrossRef]

15. Garbaa, Z.N.; Rahima, A.A. Evaluation of optimal activated carbon from an agricultural waste for the removal of para-chlorophenol and 2,4-dichlorophenol. Process Saf. Environ. Prot. 2016, 102, 54-63. [CrossRef]

16. Lingamdinne, L.P.; Koduru, J.R.; Jyothi, R.K.; Chang, Y.Y.; Yang, J.K. Factors affect on bioremediation of Co (II) and $\mathrm{Pb}$ (II) onto Lonicera japonica flowers powder. Desalin. Water Treat. 2016, 57, 13066-13080. [CrossRef]

17. Suguna, M.; Siva Kumar, N. Equilibrium, kinetic and thermodynamic studies on biosorption of lead (II) and cadmium (II) from aqueous solution by polypores biomass. Indian J. Chem. Technol. 2013, 20, 57-69.

18. Nadavala, S.K.; Che Man, H.; Woo, H.S. Biosorption of phenolic compounds from aqueous solutions using pine (Pinus densiflora Sieb) bark powder. BioResources 2014, 9, 5155-5174. [CrossRef]

19. Yildiz, D.; Keskin, F.; Demirak, A. Biosorption of 2,4 Dichlorophenol onto Turkish Sweetgum bark in a batch system: Equilibrium and kinetic study. Acta Chim. Slov. 2017, 64, 237-247. [CrossRef]

20. Siva, K.N.; Asif, M.; Al-Hazzaa, M.I.; Ibrahim, A.A. Biosorption of 2,4,6-trichlorophenol from aqueous medium using agro-waste: Pine (Pinus densiflora Sieb) bark powder. Acta Chim. Slov. 2018, 65, 221-230. [CrossRef]

21. Kusmierek, K.; Swiatkowski, A.; Dabek, L. Removal of 2,4,6-trichlorophenol from aqueous solutions using agricultural waste as low-cost adsorbents. Environ. Prot. Eng. 2017, 43, 149-163.

22. Ucun, H.; Bayhan, Y.K.; Kaya, Y.; Cakici, A.; Algur, O.F. Biosorption of lead (II) from aqueous solution by cone biomass of Pinus sylvestris. Desalination 2003, 154, 233-238. [CrossRef]

23. Niyaz, M.M.; Hayati, B.; Arami, M.; Lan, C. Adsorption of textile dyes on Pine Cone from colored wastewater: Kinetic, equilibrium and thermodynamic studies. Desalination 2011, 268, 117-125.

24. Ofomaja, A.E.; Naidoo, E.B. Biosorption of lead (II) onto pine cone powder: Studies on biosorption performance and process design to minimize biosorbent mass. Carbohydr. Polym. 2010, 82, 1031-1042. [CrossRef]

25. Ofomaja, A.E.; Naidoo, E.B.; Modise, S.J. Removal of copper (II) from aqueous solution by pine and base modified pine cone powder as biosorbent. J. Hazard. Mater. 2009, 168, 909-917. [CrossRef] 
26. Ofomaja, A.E.; Naidoo, E.B.; Modise, S.J. Biosorption of copper (II) and lead (II) onto potassium hydroxide treated pine cone powder. J. Environ. Manag. 2010, 91, 1674-1685. [CrossRef]

27. Ofomaja, A.E.; Pholosi, A.; Naidoo, E.B. Application of raw and modified pine biomass material for cesium removal from aqueous solution. Ecol. Eng. 2015, 82, 258-266. [CrossRef]

28. Ofomaja, A.E.; Pholosi, A.; Naidoo, E.B. Kinetics and competitive modeling of cesium biosortion onto chemically modified pine cone powder. J. Taiwan Inst. Chem. Eng. 2013, 44, 943-951. [CrossRef]

29. Kumar, N.S.; Asif, M.; Al-Hazzaa, M.I. Adsorptive removal of phenolic compounds from aqueous solutions using pine cone biomass: Kinetics and equilibrium studies. Environ. Sci. Pollut. Res. 2018, 25, 21949-21960. [CrossRef]

30. Nassar, N.N.; Arar, L.A.; Marei, N.N.; Abu Ghanim, M.M.; Dwekat, M.S.; Sawalha, S.H. Treatment of olive mill based wastewater by means of magnetic nanoparticles: Decolourization, dephenolization and COD removal. Environ Nanotechnol. Monit. Manag. 2014, 1-2, 14-23. [CrossRef]

31. Jayaramudu, J.; Guduri, B.R.; Varada, R.A. Characterization of new natural cellulosic fabric Grewia tilifolia. Carbohydr. Polym. 2010, 79, 847-855. [CrossRef]

32. Mas Haris, M.R.H.; Sathasivam, K. The removal of methyl red from aqueous solutions using banana pseudo stem fibers. Am. J. Appl. Sci. 2009, 6, 1690-1700.

33. Malkoc, E. Ni (II) removal from aqueous solutions using cone biomass of Thujaorientalis. J. Hazard. Mater. 2006, 137, 899-908. [CrossRef] [PubMed]

34. Barka, N.; Abdennouri, M.; El Makhfouk, M.; Qourzal, S. Biosorption characteristics of cadmium and lead onto eco-friendly dried cactus (Opuntia ficusindica) Cladodes. J. Environ. Chem. Eng. 2013, 1, 144-149. [CrossRef]

35. Hamdaoui, O.; Naffrechoux, E. Modeling of adsorption isotherms of phenol and chlorophenols onto granular activated carbon: Part I. Two-parameter models and equations allowing determination of thermodynamic parameters. J. Hazard. Mater. 2007, 147, 381-394. [CrossRef] [PubMed]

36. Rengaraj, S.; Moon, S.H.; Sivabalan, R.; Arabindoo, B.; Murugesan, V. Agricultural solid waste for the removal of organics: Adsorption of phenol from water and wastewater by palm seed coat activated carbon. Waste Manag. 2002, 22, 543-548. [CrossRef]

37. Hameed, B.H. Equilibrium and kinetics studies of 2,4,6-trichlorophenol adsorption onto activated clay. Coll. Surf. A Physicochem. Eng. Asp. 2007, 307, 45-52. [CrossRef]

38. Hameed, B.H.; Tan, I.A.W.; Ahmad, A.L. Adsorption isotherm, kinetic modeling and mechanism of 2,4,6-trichlorophenol on coconut husk-based activated carbon. Chem. Eng. J. 2008, 144, 235-244. [CrossRef]

39. Tan, I.A.W.; Ahmad, A.L.; Hameed, B.H. Adsorption isotherms, kinetics, thermodynamics and desorption studies of 2,4,6-trichlorophenol on oil palm empty fruit bunch-based activated carbon. J. Hazard. Mater. 2009, 164, 473-482. [CrossRef]

40. Radhika, M.; Palanivelu, K. Adsorptive removal of chlorophenols from aqueous solution by low cost adsorbent-Kinetics and isotherm analysis. J. Hazard. Mater. 2006, 138, 116-124. [CrossRef]

41. Chakravarty, P.; Sarma, N.S.; Sarma, H.P. Removal of lead (II) from aqueous solution using heartwood of Areca catechu powder. Desalination 2010, 256, 16-21. [CrossRef]

42. Zhang, D.; Zhao, G.; Yu, J.; Yan, T.; Zhu, M.; Jiao, F. Thermodynamic and kinetic studies of effective adsorption of 2,4,6-trichlorophenol onto calcine $\mathrm{Mg} / \mathrm{Al}-\mathrm{CO}_{3}$ layered double hydroxide. J. Wuhan Univ. Technol. Mater Sci. Ed. 2016, 31, 1211-1218. [CrossRef]

43. Liu, S.; Pan, J.; Cao, J.; Dai, X.; Meng, M.; Wu, R.; Yao, J.; Yan, Y. Simultaneous removal of Pb (II) and 2,4,6-trichlorophenol by a hierarchical porous PU@PDA@MSNs sponge with reversible "shape memory" effect. Chem. Eng. J. 2016, 284, 10-20. [CrossRef]

44. Denizli, A.; Cihangir, N.; Tuzmen, N.; Alsancak, G. Removal of chlorophenols from aquatic systems using the dried and dead fungus Pleurotus sajor caju. Bioresour. Technol. 2005, 96, 59-62. [CrossRef] [PubMed]

45. Tan, I.A.W.; Ahmad, A.L.; Hameed, B.H. Preparation of activated carbon from coconut husk: Optimization study on removal of 2,4,6-trichlorophenol using response surface methodology. J. Hazard. Mater. 2008, 153, 709-717. [CrossRef] [PubMed]

46. Aziz, A.S.A.; Manaf, L.A.; Man, H.C.; Kumar, N.S. Equilibrium studies and dynamic behavior of cadmium adsorption by palm oil boiler mill fly ash (POFA) as a natural low-cost adsorbent. Desalin. Water Treat. 2015, 54, 1956-1968. [CrossRef] 
47. Lagergren, S.Y. Zur Theorie der sogenannten adsorption geloster stoffe, Kungliga Svenska Vetenskapsakademiens. Handlingar 1898, 24, 1-39.

48. Fakhri, A.; Rashidi, S.; Asif, M.; Ibrahim, A. Microwave-assisted synthesis of SiC Nanoparticles for the efficient adsorptive removal of Nitroimidazole Antibiotics from aqueous solution. Appl. Sci. 2017, 7, 205. [CrossRef]

49. Ho, Y.S.; McKay, G. Pseudo-second order model for sorption processes. Process Biochem. 1999, 34, 451-465. [CrossRef]

50. Suguna, M.; Kumar, N.S.; Sreenivasulu, V.; Krishnaiah, A. Removal of Pb (II) from aqueous solutions by using Chitosan coated Zero Valent Iron Nanoparticles. Sep. Sci. Technol. 2014, 49, 1613-1622. [CrossRef]

51. Weber, W.J.; Morris, J.C. Kinetics of adsorption on carbon from solution. J. Sanit. Eng. Div. 1963, 89, 31-60.

52. Olu-Owolabi, B.I.; Alabi, A.H.; Diagboya, P.N.; Unuabonah, E.I.; During, R.A. Adsorptive removal of 2,4,6-trichlorophenol in aqueous solution using calcined kaolinite-biomass composites. J. Environ. Manag. 2017, 192, 94-99. [CrossRef] [PubMed]

53. Fakhri, A.; Rashidi, S.; Asif, M.; Ibrahim, A. Synthesis and characterization of $\mathrm{MnS}_{2} /$ reduced graphene oxide nanohybrid: An efficient adsorbent for pharmaceutical compound removal. Desalin. Water Treat. 2017, 68, 236-244. [CrossRef]

54. Siva Kumar, N.; Subba Reddy, A.; Boddu, V.M.; Krishnaiah, A. Development of chitosan-alginate based biosorbent for the removal of p-chlorophenol from aqueous medium. Toxicol. Environ. Chem. 2009, 91, 1035-1054. [CrossRef]

55. Freundlich, H.; Heller, W. The Adsorption of cis- and trans-azobenzene. J. Am. Chem. Soc. 1939, 61, $2228-2230$. [CrossRef]

56. Temkin, M.J.; Pyzhev, V. Kinetics of the synthesis of ammonia on promoted iron catalysts. J. Phys. Chem. USSR 1939, 13, 851-867.

57. Dubinin, M.M.; Radushkevich, L.V. The equation of the characteristic curve of the activated charcoal. Proc. Acad. Sci. USSR Phys. Chem. Sec. 1947, 55, 331-337.

58. Fan, J.; Zhang, J.; Zhang, C.; Ren, L.; Shi, Q. Adsorption of 2,4,6-trichlorophenol from aqueous solution onto activated carbon derived from loosestrife. Desalination 2011, 267, 139-146. [CrossRef]

59. Pan, J.; Luo, J.; Cao, J.; Liu, J.; Huang, W.; Zhang, W.; Yang, L. Competitive adsorption of three phenolic compounds to hydrophilic urea-formaldehyde macroporous foams derived from lignin-based Pickering HIPEs template. RSC Adv. 2016, 6, 93894-93904. [CrossRef]

60. Mubarik, S.; Saeed, A.; Athar, M.M.; Iqbal, M. Characterization and mechanism of the adsorptive removal of 2,4,6-trichlorophenol by biochar prepared from sugarcane baggase. J. Ind. Eng. Chem. 2016, 33, 115-121. [CrossRef]

61. Krishnaiah, D.; Anisuzzaman, S.M.; Bono, A.; Sarbatly, R. Adsorption of 2,4,6-trichlorophenol (TCP) onto activated carbon. J. King Saud Univ. Sci. 2013, 25, 251-255. [CrossRef] 